\title{
A factor analysis to find critical success factors in retail brand
}

\author{
Naser Azad*, Seyed Foad Zarifi and Somayeh Hozouri
}

Department of Management, Islamic Azad University, South Tehran Branch, Tehran, Iran

\section{H R O N I C LE A B S T RACT}

Article history:

Received October 28, 2012

Received in revised format

20 January 2013

Accepted 25 January 2013

Available online

February 22013

Keywords:

Factor analysis

Retail brand

Market share adjustment

\begin{abstract}
The present exploratory study aims to find critical components of retail brand among some retail stores. The study seeks to build a brand name in retail level and looks to find important factors affecting it. Customer behavior is largely influenced when the first retail customer experience is formed. These factors have direct impacts on customer experience and satisfaction in retail industry. The proposed study performs an empirical investigation on two well-known retain stores located in city of Tehran, Iran. Using a sample of 265 people from regular customers, the study uses factor analysis and extracts four main factors including related brand, product benefits, customer welfare strategy and corporate profits using the existing 31 factors in the literature.
\end{abstract}

(c) 2013 Growing Science Ltd. All rights reserved.

\section{Introduction}

Brand is one of the most important components of business development in retain industry. In fact, many retail industries spend significant amount of cost and efforts for marketing in two national and domestic levels (Kachersky, 2011). These advertisements include various mass Medias such as TV advertisement, journals, etc. It is always important to spend suitable amount of money for business development using advertisement plans. Broyles et al. (2011) examined the comparative impact of manufacturer brands and retail brands on customers' purchase behaviors. The study disclosed that customers' loyalty to retail brand(s) had bigger impact on their purchase behavior than manufacturer brand(s). They also found that attitude towards store brands directly impacted one's propensity to switch to retail brands, and mediated relationships between loyalty to manufacturer/retail brands and one's propensity to switch to retail brand(s). Choi (2008) presented a practical methodology for a retailer's pricing decisions for a store brand in association with the corresponding national brand's price and the method allows managers to find the optimal price for a store brand using survey data. 
De Jong and Den Hartog (2007) investigated on how leaders could impact employees' innovative behavior. They explored leadership behaviors, which stimulate employees' idea generation and application behavior and the survey was carried out among knowledge-intensive service firms. They reported that there were 13 relevant leadership behaviors, although innovative behavior was crucial in such firms, it had received very little attention from researchers. Leaders impact employees' innovative behavior both through their deliberate actions aiming to stimulate idea generation and application.

Guenzi et al. (2009) developed and examined a model of customer trust in a retail service setting. The model included three levels of the customer-to-store relationship including customer to sales associates, customer to store branded products, and customer to the store itself. In their survey, Trust in the salesperson and trust in store branded products had positive impacts on overall store trust. In addition, store trust, increased perceived value and loyalty intentions. Granot et al. (2010) investigated how female shoppers make meaning in a branded-retail store shopping experience. The investigation extended research on retail consumers' decision-making and the retail shopping experience based on hermeneutic phenomenology. They conducted some interviews with respondents, who were self-identified customers of a leading intimate apparel retailer. They recommended that consumers' retail shopping decision-making would incorporate a complex set of interactive components brand-driven and simultaneously would impact and were influenced by the interaction of in-store shopping and retail setting. Their findings indicated that a rich understanding of the consumer decision-making process was achievable by incorporating the actual in-store experience, consumers' prior contextual experiences and expectations associated with retail visits.

Jones et al. (2010) explored the emergence and development of experience stores and considered their potential impact in fostering consumer brand relationships and their effect on the retail landscape. They also provided an accessible review of the emergence of experience stores and their effect in developing relationships between brands and consumers. Nisar (2011) implemented property rights method to demonstrate that intellectual property (IP) securitization could provide mechanisms, which explicitly describe ownership of intangible assets within the securitization structure and it could enable a company to raise funds against these assets. They also provided some evidence where these mechanisms were not overly restrictive and could be implemented more widely to help fund retail franchise growth and expansion.

Poolthong and Mandhachitara (2009) explored how social responsibility initiatives could impact perceived service quality and brand impact from the perspective of retail banking customers in Bangkok, Thailand. They also examined the effect of trust as a mediating variable between perceived service quality and brand impact. The results of the study showed how corporate social responsibility (CSR) initiatives impact service quality perceptions and investigated CSR's effect on trust and affective attitudes of customers towards their banks.

Wallace and de Chernatony (2009) explored managers' and employees' perspectives about service brand sabotage at the front line in retail banking and identified employee fear, overwork and compliance demands as issues which impact job dissatisfaction, consumer resentment and employee insecurity.

This paper presents an empirical survey to investigate different factors influencing brand development using factor analysis, which has recently become a popular method. For instance, Azad et al. (2013) studied the effect of new techniques of advertisement in product development. They designed a questionnaire for one of Iranian soft drink producers, which consisted of 274 questions in Likert scale and used factor analysis to investigate the results. Azad and Masoumi (2013) detected important factors, which are impacting competitive advantage. Azad et al. (2012) presented an empirical investigation to learn more about challenges in carpet industry using factor analysis. 


\section{The proposed study}

This study seeks to build a brand name in retail level and looks to find important factors affecting it. Customer behavior is largely influenced when the first retail customer experience is formed. These factors have direct impacts on customer experience and satisfaction in retail industry. The proposed study performs an empirical investigation on two well-known retain stores located in city of Tehran, Iran. Using a sample of 265 people from regular customers, the study uses factor analysis and extracts four main factors including related brand, product benefits, customer welfare strategy and corporate profits using the existing 31 factors in the literature.

Cronbach alpha is calculated as $88.1 \%$, which is well above the minimum desirable limit of 0.70 . There are 18 variables and using factor analysis, we extract six factors where Kaiser-Meyer-Olkin Measure of Sampling Adequacy was $70.9 \%$ (Chi-Square $=3249 \mathrm{df}=210$ Sig. $=0.000$ ), which also confirms the results of our survey.

\section{The results}

The results of the implementation of factor analysis have provided four factors including related brand, product advantage, customer welfare and profitability, which are explained next.

\subsection{Related brand}

The first factor is known as related brand, which includes six sub-factor including fashion, customer loyalty, brand value, product advertisement effectiveness, investment in domestic market and good performance of distribution channels. Table 1 shows the weights for all factors and the results indicate that brand value is the most important items in this part of our survey followed by customer loyalty, fashion, good performance of distribution channels, product advertisement effectiveness and Investment in domestic market.

\section{Table 1}

The summary of factor analysis for related brand

\begin{tabular}{lcccc}
\hline Option & Factor weight & Eigenvalues & \% of variance & Accumulated \\
\hline Fashion & 0.746 & & & \\
$\begin{array}{l}\text { Customer loyalty } \\
\text { Brand value }\end{array}$ & 0.785 & & & \\
$\begin{array}{l}\text { Product advertisement } \\
\text { effectiveness }\end{array}$ & 0.854 & 3.474 & 57.908 & 57.908 \\
$\begin{array}{l}\text { Investment in domestic market } \\
\begin{array}{l}\text { Good performance of distribution } \\
\text { channels }\end{array}\end{array}$ & 0.631 & & & \\
\hline
\end{tabular}

\subsection{Product advantage}

Product advantage is the second factor, which includes five sub-factor including product diversity, physical conditions of stores, prevention any conflict of interest between supplier and retailor, being exclusive and after sale services. Table 2 demonstrates the weights for all factors and the results clearly show that physical conditions of stores is the most important items in this part of our survey followed by product diversity and after sale services. Cronbach alpha has been calculated as 0.811 , which is well above the minimum desirable limit. 
Table 2

The summary of factor analysis for product advantage

\begin{tabular}{lcccc}
\hline Option & Factor weight & Eigenvalues & \% of variance & Accumulated \\
\hline Product diversity & 0.652 & & & \\
Physical conditions of stores & 0.727 & 2.856 & 57.114 & 57.114 \\
Prevention any conflict of interest & 0.577 & & & \\
between supplier and retailor & & & & \\
Being exclusive & 0.578 & & & \\
After sale services & 0.612 & & & \\
\hline
\end{tabular}

\subsection{Customer Welfare}

Customer welfare is the third factor, which includes four factors including "relationship between product characteristics with customer's interest", "using multimedia advertisements", "meeting customers' benefits" and "using several retail stores". Table 3 presents the weights for all factors and the results clearly demonstrate that "relationship between product characteristics" is the most important items in this part of our survey followed by "using multimedia advertisements" and "using several retail stores". Cronbach alpha has been calculated as 0.803 , which is well above the minimum desirable limit.

\section{Table 3}

The summary of factor analysis for product advantage

\begin{tabular}{lcccc}
\hline Option & Factor weight & Eigenvalues & \% of variance & Accumulated \\
\hline $\begin{array}{l}\text { Relationship between product } \\
\text { characteristics }\end{array}$ & 0.749 & 2.522 & 63.051 & 63.051 \\
$\begin{array}{l}\text { Using multimedia advertisements } \\
\text { Meeting customers' benefits }\end{array}$ & 0.743 & & & \\
Using several retail stores & 0.511 & & & \\
\hline
\end{tabular}

\subsection{Profitability}

Profitability is the last factor, which includes three sub-factors including advantage of using good will to receive loan and market development, internet development business and outlook profitability. Table 4 demonstrates the weights for all factors and the results show that "using good will to receive loan and market development" is the most important items in this part of our survey followed by "internet development business" and "outlook profitability".

\section{Table 4}

The summary of factor analysis for product advantage

\begin{tabular}{lcccc}
\hline Option & Factor weight & Eigenvalues & $\%$ of variance & Accumulated \\
\hline $\begin{array}{l}\text { Using good will to receive loan } \\
\text { and market development }\end{array}$ & 0.729 & & & \\
Internet development business & 0.502 & & & \\
Outlook profitability & 0.806 & 1.574 & 52.469 & 52.469 \\
\hline
\end{tabular}

\section{Conclusion}

Developing a good brand has been a major concern among business owners and it is always important to understand important factors influencing brand development. The present study has implemented factor analysis to find out important factors in brand development. The results of the implementation 
of factor analysis have provided four factors including "related brand”, "product advantage”, “customer welfare” and "profitability".

The first factor included six components and "brand value" has been the most important items in our survey followed by "customer loyalty", "fashion”, "good performance of distribution channels", "product advertisement effectiveness" and "investment in domestic market". "Product advantage” was the second factor with five sub-factor including "product diversity", "physical conditions of stores", "prevention any conflict of interest between supplier and retailor", "being exclusive and after sale services". The results have clearly shown that "physical conditions of stores" was the most important items in our survey followed by "product diversity" and "after sale services".

Customer welfare has been the third factor, which includes four factors including "relationship between product characteristics with customer's interest", "using multimedia advertisements", "meeting customers' benefits" and "using several retail stores". The results have clearly demonstrated that "relationship between product characteristics" has been the most important items in our survey followed by "using multimedia advertisements" and "using several retail stores". Profitability has been the last factor with three sub-factors including "advantage of using good will to receive loan and market development”, “internet development business" and "outlook profitability”. The results have shown that "using good will to receive loan and market development" was the most important items in this part of our survey followed by "internet development business" and "outlook profitability".

\section{Acknowledgment}

The authors would like to thank the anonymous referees for constructive comments on earlier version of this paper.

\section{References}

Azad, N., \& Masoumi, M. (2012). The impact of packaging on product competition. Management Science Letters, 2(8), 2789-2794.

Azad, N., Seyed Aliakbar, S.M., \& Ansari, M. (2012). Investigating knowledge management critical success factors in carpet industry. Management Science Letters, 2(8), 2717-2722.

Azad, N., Zarifi, S.F., Hozori, S., \& Hashemi, S. (2013). A survey on critical factors influencing new advertisement methods. Management Science Letters, 3(2), 569-574.

Broyles, S. A., Ross, R. H., Davis, D., \& Leingpibul, T. (2011). Customers' comparative loyalty to retail and manufacturer brands. Journal of Product \& Brand Management, 20(3), 205-215.

Choi, S. C. (2008). Optimal retail pricing of a store brand. Journal of Product \& Brand Management, 17(2), 108-114.

De Jong, J. P., \& Den Hartog, D. N. (2007). How leaders influence employees' innovative behaviour. European Journal of Innovation Management, 10(1), 41-64.

Guenzi, P., Johnson, M. D., \& Castaldo, S. (2009). A comprehensive model of customer trust in two retail stores. Journal of Service Management, 20(3), 290-316.

Granot, E., Greene, H., \& Brashear, T. G. (2010). Female consumers: Decision-making in branddriven retail. Journal of Business Research, 63(8), 801-808.

Jones, P., Comfort, D., Clarke-Hill, C., \& Hillier, D. (2010). Retail experience stores: experiencing the brand at first hand. Marketing Intelligence \& Planning,28(3), 241-248.

Kachersky, L. (2011). Reduce Content or Raise Price? The Impact of Persuasion Knowledge and Unit Price Increase Tactics on Retailer and Product Brand Attitudes. Journal of Retailing, 87(4), 479488.

Nisar, T. M. (2011). Intellectual Property Securitization and Growth Capital in Retail Franchising. Journal of Retailing, 87(3), 393-405. 
Poolthong, Y., \& Mandhachitara, R. (2009). Customer expectations of CSR, perceived service quality and brand effect in Thai retail banking. International Journal of Bank Marketing, 27(6), 408-427.

Wallace, E., \& de Chernatony, L. (2009). Exploring brand sabotage in retail banking. Journal of Product \& Brand Management, 18(3), 198-211. 